\title{
Current Two EGFR Mutations in Lung Adenocarcinoma - Case Report
}

\author{
Současné dvě EGFR mutace u plicního adenokarcinomu - \\ kazuistika
}

\author{
Svaton M. ${ }^{1}$, Pesek M. ${ }^{1}$, Chudacek Z. ${ }^{2}$, Vosmiková H. ${ }^{3}$ \\ 'Department of Pneumology, Charles University in Prague, Faculty of Medicine in Pilsen, University Hospital Pilsen, Czech Republic \\ 2 Department of Radiology, Charles University in Prague, Faculty of Medicine in Pilsen, University Hospital Pilsen, Czech Republic \\ ${ }^{3}$ Department of Pathology, Charles University in Prague, Faculty of Medicine in Hradec Kralove, University Hospital Hradec Kralove, Czech Republic
}

\begin{abstract}
Summary
Nowadays, EGFR-TKIs (epidermal growth factor receptor-tyrosine kinase inhibitors) targeted therapy is well established treatment for patients with the so-called EGFR common mutations with advanced or metastatic non-small cell lung cancer. The efficacy for the so-called rare and especially for the very rare complex EGFR mutations is not clear. We describe a case of a 63-year-old female with metastatic non-small cell lung cancer with complex EGFR mutation $(\mathrm{G} 719 \mathrm{X}+\mathrm{S} 768 \mathrm{I})$ who had been treated by gefitinib. She achieved progression free survival within eight months. Then, we discuss our case with other literature case reports. Together, it seems that described complex EGFR mutation has a relatively good sensitivity for EGFR-TKIs treatment.
\end{abstract}

\section{Key words}

non-small cell lung cancer - EGFR gene - EGFR protein - complex mutations - rare EGFR mutations - EGFR-TKIs

\section{Souhrn}

Cílená terapie pomocí EGFR-TKIs (epidermal growth factor receptor-tyrosine kinase inhibitors) je v současné době dobře zavedenou léčbou pro pacienty s tzv. častými EGFR mutacemi s pokročilým nebo metastatickým nemalobuněčným karcinomem plic. Účinnost této léčby pro tzv. vzácné a obzvláště pak pro tzv. komplexní EGFR mutace není zcela jasná. V naší kazuistice popisujeme prípad 63leté ženy s metastatickým nemalobuněčným karcinomem plic s komplexní EGFR mutací (G719X + S768l), která byla léčena gefitinibem. Doba do progrese dosáhla osm měsíců. Následně diskutujeme naší kazuistiku s literárně zveřejněmými obdobnými případy. Celkově se zdá, že popisovaná komplexní mutace má relativně dobrou citlivost pro léčbu pomocí EGFR-TKIs.

\section{Klíčová slova}

nemalobuněčný karcinom plic - EGFR gen - EGFR protein - complex mutations - rare EGFR mutations - EGFR-TKIs
The authors declare they have no potential conflicts of interest concerning drugs, products, or services used in the study.

Autoři deklarují, že v souvislosti s predmětem studie nemaji žádné komerční zájmy.

The Editorial Board declares that the manuscript met the ICMJE "uniform requirements" for biomedical papers.

Redakční rada potvrzuje, že rukopis práce splnil ICMJE kritéria pro publikace zasílané do biomedicínských časopisů.

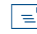

Martin Svaton, MD, Ph.D.

Department of Pneumology

Charles University in Prague

Faculty of Medicine in Pilsen University Hospital Pilsen dr. Edvarda Beneše 13

30599 Pilsen

Czech Republic

e-mail: svatonm@gmail.com

Submitted/Obdrženo: 24. 11. 2014 Accepted/Príijato: 4. 2. 2015

http://dx.doi.org/10.14735/amko2015134 


\section{Introduction}

Lung cancer is the leading and main cause of death associated with malignancies worldwide [1]. However, the prognosis of a patient differs greatly according to the type and stage of the tumor [2]. Mutations in the gene for epidermoid growth factor receptor (EGFR) were detected as strong predictive and prognostic markers in NSCLC $[2,3]$. EGFR mutations were found approximately in $10 \%$ to $20 \%$ of the Caucasian population and from $30 \%$ to $60 \%$ of the Asian population with NSCLC [4]. Their frequent occurrence was demonstrated in adenocarcinoma, women and non-smokers [5,6]. Exon 19 deletions and point mutations in exon 21 constitute $80-90 \%$ of EGFR mutations [7,8]. These mutations are known as common mutations. Other remaining mutations are known as rare mutations. Their predictive value is often not clear. EGFR mutations may also occur in combination, either as two common, common and rare or two rare mutations together [5]. We present a case report of a patient with two rare mutations treated with gefitinib.

\section{Case report}

A patient, 63-year-old woman, smoker (40 pack for years) without any severe comorbidities, diagnosis - adenocarci- noma of the lower lobe of left lung with multiple bilateral lung metastasis, mediastinal lymphadenopathy and solid metastasis to liver and to thoracic vertebra (Th7) was established. Adenocarcinoma was verified histologically in the regional hospital. The diagnosis was staged as T1N2M1b, stage IV (Fig. 1). Genetic testing from obtained histological sample was performed in an accredited laboratory of university hospital by Cobas (using RT-PCR technology) and confirmed by direct PCR sequencing. These methods revealed an activating double EGFR mutation ( $\mathrm{S} 768 \mathrm{I}$ on exon 20 plus G719X on exon 18). The patient was treated with gefitinib in a standard dose of $250 \mathrm{mg}$ per day from October 2013. We observed regression of tumor through X-ray and also milder symptoms of the patient (dyspnoe, cough, loss of weight) a month later.

Regression of the primary tumor was confirmed using CT scans (Fig. 2) in February 2014 , at the same time obviously fewer lung metastases were detected, mediastinal lymphadenopathy disappeared as well as liver metastases.

The next controls established disease stabilization until June 2014. In June, progression of lung metastases and especially novel multiple brain metastasis (Fig. 3, 4) were described on CT scans. Therefore, the treatment with gefitinib (which was very well tolerated) was finished after eight months. The patient was transferred back to the regional hospital with proposal of palliative radiation of cranial metestases and proposal of initiation of the $2^{\text {nd }}$ line treatment.

\section{Discussion}

Sensitive mutation of EGFR (EGFR M+) represents a significant predictive factor for treatment of EGFR-TKI [9]. In EGFR $M+$ patients, gefitinib and erlotinib demonstrated improvement in objective response rate (ORR) and time to disease progression (PFS) compared with established chemotherapy [10]. Therefore, EGFR-TKIs is considered as the standard treatment for these patients in the $1^{\text {st }}$ line. In a lot of large studies, deletion of exon 19 and the L858R point mutation in exon 21 were confirmed as sensitive mutations [8]. However, there is a number of other, so-called rare mutations in exons 18 to 21 of the EGFR gene $[7,8]$. Response to treatment has not been clearly determined yet because of small number of patients [8], but literature for the special mutation can show at least a trend in response to treatment with EGFR-TKI.

Rare mutations are described in the literature, approximately in 10\%

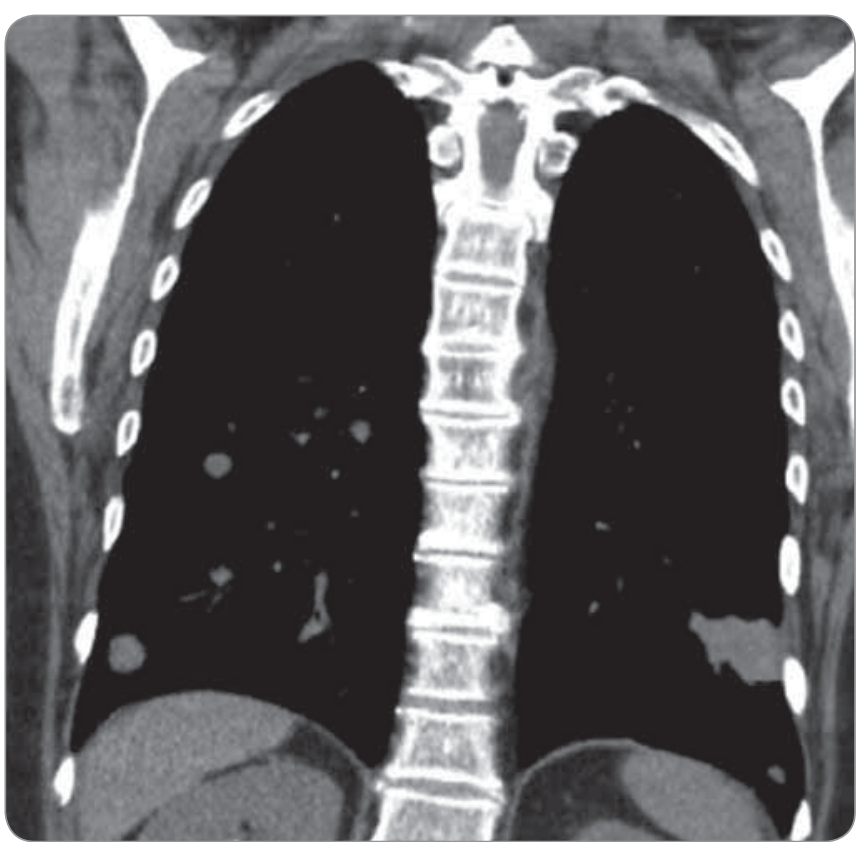

Fig. 1. Input CT of lung and mediastinum (8/2013).

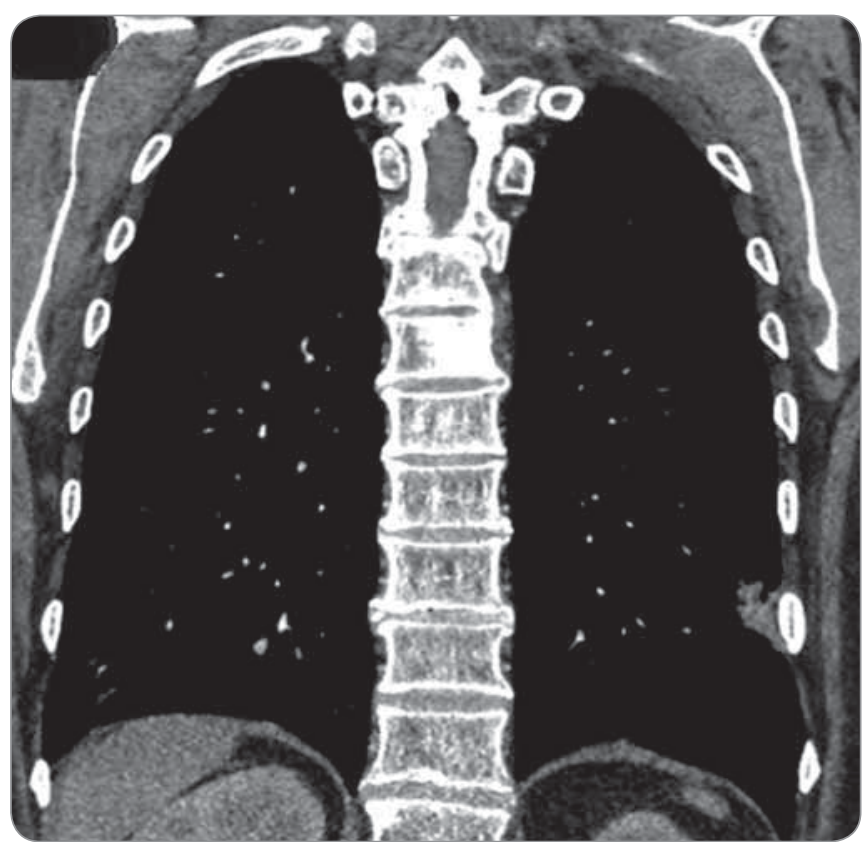

Fig. 2. Control CT of lung and mediastinum - regression of tu$\operatorname{mor}(2 / 2014)$. 


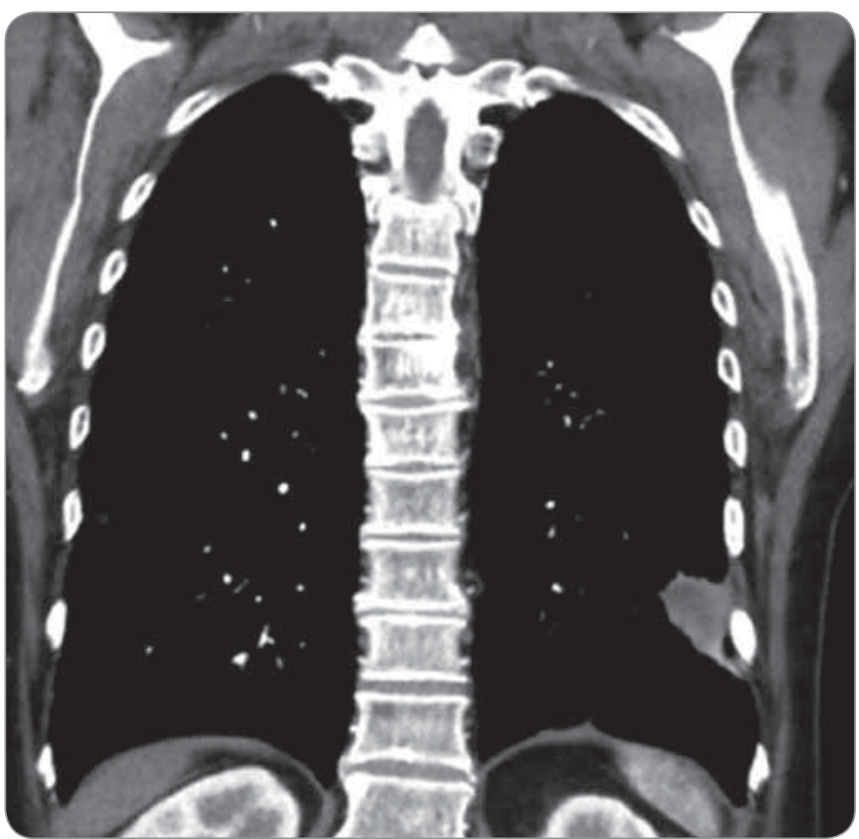

Fig. 3. Control CT of lung and mediastinum - progression of tu$\operatorname{mor}(6 / 2014)$

of cases [11,12]. G719X and L861X, described in our patient, are among the more frequent of them [8,13-15]. G719X mutation occurs in approximately $3 \%$ of EGFR $M+$ patients and several patients treated with EGFR-TKIs have been described $[4,8,12,13,16]$. Response to treatment is published from approximately one third to approximately $55 \%[4,8,12,13]$. PFS of these patients is also described as a very heterogenous from less than three months to eight months $[4,12]$.

Compared with classical mutations, a decreased sensitivity of this mutation to EGFR-TKIs was proven in vitro $[16,17]$. Higher sensitivity has been described for EGFR of higher generations [10,12]. Difference in PFS can be caused by different subtypes of G719X mutation, but clear evidence is lacking $[1,12,17]$. S678X mutation has ORR about $50-60 \%[4,8]$. PFS is usually also shorter than in patients with classical mutations [4,12]. Higher concentrations of EGFR-TKIs to induce a response are necessary in vitro [12]. Generally, mutations G719X and L861X are considered as moderately sensitive to EGFR-TKIs, both in vitro $[4,17]$ and in vivo [9].

G179X and L861Q quite often appeared as a complex mutation - G719X up to $50 \%$ and L861X to $25 \%$ [13]. Toge- ther with classical EGFR mutations (especially L858R), they belong to the most common 'components' of complex mutations [13]. Apparently, the above mentioned fact can show that the composition of these mutations will result in complex mutations partially sensitive to the EGFR-TKI. However, as evidenced in the literature, complex mutations should be considered separately as independent units and not as 'composition' of two individual mutations $[6,18]$. It is due to resulting changes in the spatial distribution of EGFR molecule in complex mutations [18]. Generally, two frequent mutations together have the same or better response to EGFR-TKI, frequent mutation with rare (non-resistant) mutation usually shows equal sensitivity and two rare (non-resistant) mutations show slightly lower sensitivity to EGFR-TKI [8]. Relatively common complex mutation G719X + L861X was described by several authors [2,4,8,19-21], where EGFR-TKI was administered in some of these cases. Keam et al treated one patient with this mutation with gefitinib, PFS reached 7.9 months and OS time was not reached after 26 months of patient's observation [8]. Lund-Iversen et al then achieved even a better result when the patient was treated for 14 months until progression of the disease [2]. Wu et al then described low efficacy when one patient experienced partial response $(P R)$, but the second soon progressed [4]. In the publication, Kobayashi et al showed PR response in two patients treated with erlotinib, but PFS did not exceed 8 months [19]. Our case study points at a moderate response of mutation G179X + L861X to EGFR-TKIs treatment, what is in accordance with a few published cases. Together, it seems that the described complex EGFR mutation has relatively good sensitivity for EGFR-TKIs treatment.

\section{References}

1. Hsieh MH, Fang YF, Chang WC et al. Complex mutation patterns of epidermal growth factor receptor gene associated with variable responses to gefitinib treatment in patients with non-small cell lung cancer. Lung Cancer 2006; 53(3): 311-322.

2. Lund-Iversen $M$, Kleinberg $L$, Fjellbirkeland $L$ et al. Clinicopathological characteristics of 11 NSCLC patients with EGFR-exon 20 mutations. J Thorac Oncol 2012; 7(9): 1471-1473. doi: 10.1097/JTO.0b013e3182614a9d. 3. Fiala O, Pešek M, Fínek J et al. EGFR mutations in patients with advanced NSCLC. Klin Onkol 2012; 25(4): 267-273. doi: 10.14735/amko2012267.

4. Wu JY, Yu CJ, Chang YC et al. Effectiveness of tyrosine kinase inhibitors on „uncommon" epidermal growth factor receptor mutations of unknown clinical significance in non-small cell lung cancer. Clin Cancer Res 2011; 17(11): 3812-3821. doi: 10.1158/1078-0432.CCR-10-3408. 5. Svoboda M, Fabian P, Slaby O et al. EGFR tyrosine kinase inhibitors as a targeted therapy for bronchioloalveolar carcinoma of the lung: a case report of a clinically prompt and intensive response and literature review. Klin Onkol 2010; 23(4): 224-230. 
6. Tam IY, Leung EL, Tin VP et al. Double EGFR mutants containing rare EGFR mutant types show reduced in vitro response to gefitinib compared with common activating missense mutations. Mol Cancer Ther 2009; 8(8): 2142-2151. doi: 10.1158/1535-7163.MCT-08-1219.

7. Heneberg P. Indication of EGFR kinase inhibitors should be refined. Klin Onkol 2011; 24(2): 87-93.

8. Keam B, Kim DW, Park JH et al. Rare and complex mutations of epidermal growth factor receptor, and efficacy of tyrosine kinase inhibitor in patients with non-small cell ung cancer. Int J Clin Oncol 2014: 19(4): 594-600. doi: 10.1007/s10147-013-0602-1

9. D’Arcangelo M, D'Incecco A, Cappuzzo F. Rare mutations in non-small-cell lung cancer. Future Oncol 2013. 9(5): 699-711. doi: 10.2217/fon.13.16.

10. Chen X, Zhu Q, Zhu L et al. Clinical perspective of afatinib in non-small cell lung cancer. Lung Cancer 2013; 81(2): 155-161. doi: 10.1016/j.lungcan.2013.02.021.

11. Sharma A, Tan TH, Cheetham G et al. Rare and novel epidermal growth factor receptor mutations in non-small-cell lung cancer and lack of clinical response to gefitinib in two cases. J Thorac Oncol 2012; 7(5): 941-942. doi: 10.1097/JTO.0b013e31825134ac.
12. Watanabe S, Minegishi $Y$, Yoshizawa $\mathrm{H}$ et al. Effectiveness of gefitinib against non-small-cell lung cancer with the uncommon EGFR mutations G719X and L861Q. J Thorac Oncol 2014; 9(2): 189-194. doi: 10.1097/JTO.0000000000000048.

13. Beau-Faller M, Prim N, Ruppert AM et al. Rare EGFR exon 18 and exon 20 mutations in non-small-cell lung cancer on 10117 patients: a rarmulticentre observational study by the French ERMETIC-IFCT network. Ann Onco 2014; 25(1): 126-131. doi: 10.1093/annonc/mdt418. 14. Zhang GC, Lin JY Wang Z et al. Epidermal growth factor receptor double activating mutations involving both exons 19 and 21 exist in Chinese non-small cell lung cancer patients. Clin Oncol (R Coll Radiol) 2007; 19(7): 499-506. 15. De Pas T, Toffalorio F, Manzotti M et al. Activity of epidermal growth factor receptor-tyrosine kinase inhibitors in patients with non-small cell lung cancer-harboring rare epidermal growth factor receptor mutations. J Thorac Oncol 2011; 6(11): 1895-1901. doi: 10.1097/JTO.0b013e318227e8c6

16. Tam IY, Leung EL, Tin VP et al. Double EGFR mutants containing rare EGFR mutant types show reduced in vitro response to gefitinib compared with common acti- vating missense mutations. Mol Cancer Ther 2009; 8(8): 2142-2151. doi: 10.1158/1535-7163.MCT-08-1219.

17. Hata A, Yoshioka H, Fujita S et al. Complex mutations in the epidermal growth factor receptor gene in non-small cell lung cancer. J Thorac Oncol 2010; 5(10): 1524-1528. doi: 10.1097/JTO.0b013e3181e8b3c5.

18. Doss GP, Rajith B, Chakraborty C et al. Structural signature of the G719S-T790M double mutation in the EGFR kinase domain and its response to inhibitors. Sci Rep 2014; 4: 5868. doi: $10.1038 /$ srep05868.

19. Kobayashi S, Canepa HM, Bailey AS et al. Compound EGFR mutations and response to EGFR tyrosine kinase inhibitors. J Thorac Oncol 2013; 8(1): 45-51. doi: 10.1097/JTO.0b013e3182781e35.

20. Yokoyama T, Kondo M, Goto Y et al. EGFR point mutation in non-small cell lung cancer is occasionally accompanied by a second mutation or amplification. Cancer Sci 2006; 97(8): 753-759.

21. Huang SF, Liu HP, Li LH et al. High frequency of epidermal growth factor receptor mutations with complex patterns in non-small cell lung cancers related to gefitinib responsiveness in Taiwan. Clin Cancer Res 2004; 10(24): 8195-8203.

\section{SOUTY̌̌̌ NA PODPORU AUTORSKÝCH TÝMO̊ PUBLIKUJÍĆCH V ZAHRANIČNÍCH ODBORNÝCH TITULECH}

\section{Odměna pro vítěze: 10000 Kč}

\section{Cíl soutěže:}

Podpořit renomé a prestiž časopisu Klinická onkologie - oficiálního časopisu ČOS ČLS JEP - u domácích i zahraničních autorů, lékařu a akademických pracovníků.

\section{Podmínky soutěže:}

1. Soutěž je určena autorským týmům, které publikují v zahraničních odborných titulech.

2. Do soutěže budou zařazeny práce publikované v zahraničních titulech od června 2014 do června 2015.

3. Ve svých článcích zaslaných $\mathrm{k}$ publikaci do zahraničního periodika budou autoři citovat práci, která byla otištěna v časopise Klinická onkologie (k vyhledání lze použit databáze www.pubmed.org nebo www.linkos.cz).

4. Do soutěže nebudou zařazeny autocitace.

5. Ze všech prací, které splní podmínky soutěže, bude redakční radou vylosována jedna, jejiž autorský tým bude oceněn částkou 10000 Kč.

\section{KLINICKÁ ONKOLOGIE




\section{Baxter}

\section{Tříkomorové All-In-One vaky pro parenterální výživu}

- Ke krytú zvýšených nárokù na proteiny a energii u kriticky nemocných mají vaky O limel N9/N9E vyšší obsah bílkovinného dusíku než jiné komerční vaky ${ }^{(1)}$

- O limel N9/N9E dodává velké množství dusíku při minimalizaci dodávky glukózy ${ }^{(1)}$

- Olimel N9/N9E z dostupných komerčních vaků vykazuje nejvyšší poměr mezi obsahem dusíku a objemem vody ${ }^{(1)}$

- Odpovídá ESPEN guidelines pro chirurgii a intenzivní péči $(2,3)$

- NOVĚ dostupný v objemech 1000 ml a 2000 ml

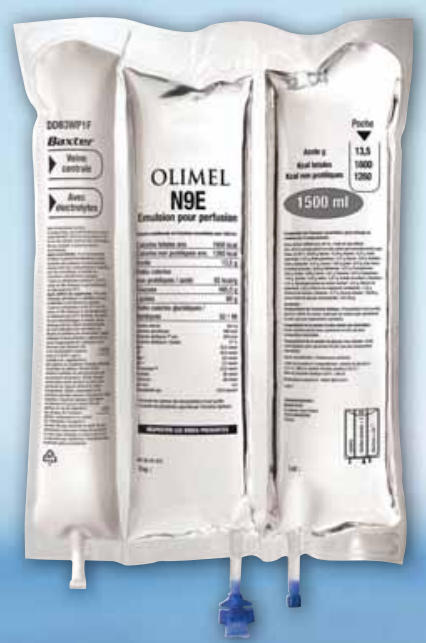

1. SPCS OLIMEL N9(E), Kabiven, SmofKabiven, NuTRIflex Lipid/Omega Special. 2. Singer P et al. Clin Nutr. 2009;28:387-400. 3. Braga M et al. Clin Nutr. 2009;28:378-386.
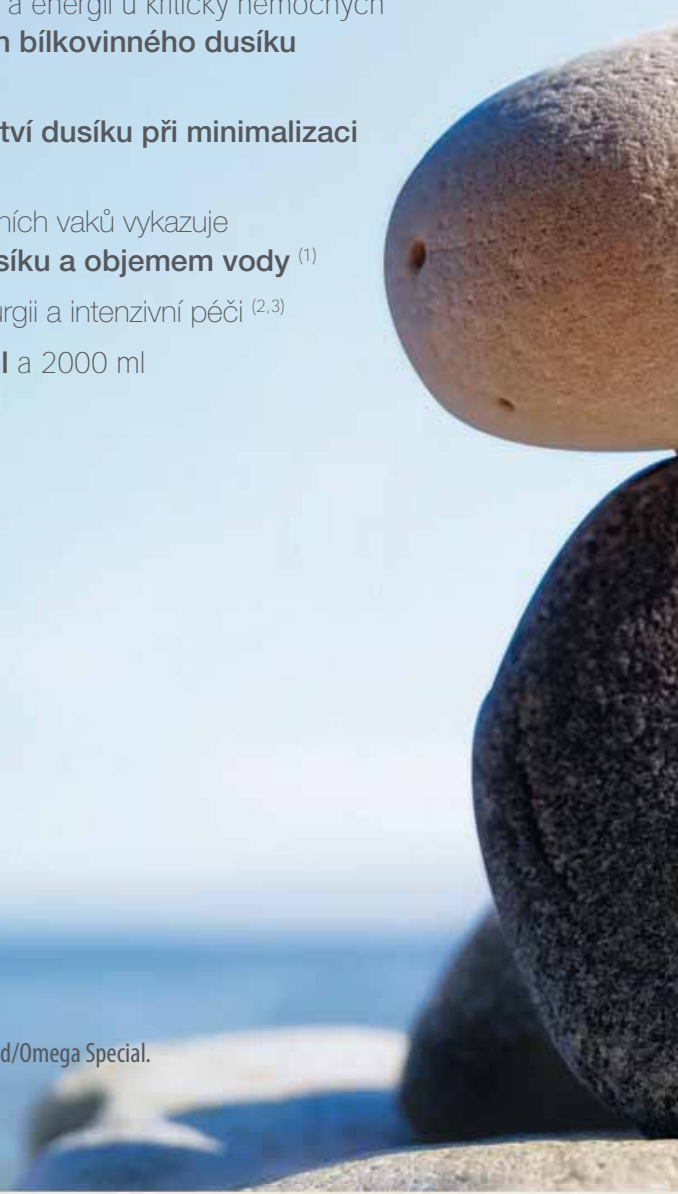

Př́pravky řady Olimel/Periolimel jsou charakterizovány obsahem dusíku v $1000 \mathrm{ml}$ (např. Periolimel N4E = 4g N/l, Olimel N5E, N7E, N9=5; 7 nebo9g N/I). Verze s elektrolyty jsou označeny E

Zkrácené informace o léčivých prípravcích OLIMEL/PERIOLIMEL

Názvy přípravků: PERIOLIMEL N4E; OLIMEL N5E; OLIMEL N7E; OLIMEL N9E; OLIMEL N9

Infuzní emulze

Kvalitativní a kvantitativní složení: Přípravky OLIMEL/PERIOLIMEL jsou dodávány v 3komorových vacích. Léćivé látky: Olivae et sojae oleum raffinatum, alaninum, argininum, acidum asparticum, acidum glutamicum, glycinum, histidinum, isoleucinum, leucinum, lysinum, methioninum, phenylalaninum, prolinum, serinum, threoninum, tryptophanum, tyrosinum, valinum, natrii acetas trihydricus, natrii glycerophosphas hydricus, kalii chloridum, magnesii chloridum hexahydricum, calcii chloridum dihydricum, glucosum. Terapeutické indikace: Prípravky OLIMEL/ PERIOLIMEL jsou indikovány pro parenterální výživu dospělých a dětí starších 2 let v prípadě, že perorální nebo enterální výživa je nemožná, nedostatečná nebo kontraindikovaná. Dávkování a způsob podání: Vzhled směsi po rekonstituci je homogenn mléčně zbarvená emulze. U dospělých a dětí starších dvou let věku Dávkování závisí na energetickém výdeji, klinickém stavu pacienta a jeho schopnosti metabolizovat složky př́pravků OLIMEL/PERIOLIMEL, jakožto i další energii nebo proteiny podané perorálně/enterálně. Proto je nutné zvolit velikost vaku s ohledem na tělesnou hmotnost pacienta. Zpưsob a délka podávání Díky své nízké osmolaritě je možné prípravek PERIOLIMEL podávat do periferní nebo centrální žily. Př́pravky OLIMEL s vysokou osmolaritou pouze do centrální žily. Doporučená doba trvání infuze pro parenteráln nutriční vak je mezi 12 a 24 hodinami. Pokud se podává prípravek dětem starším než 2 roky, je nezbytné použít vak, jehož objem koresponduje s denním dávkováním. Kontraindikace: Podáván prípravků OLIMEL/PERIOLIMEL je kontraindikováno v následujících situacích: nedonošení novorozenci, kojenci a děti mladši 2let, hypersenzitivita na vaječné proteiny, sójové nebo arašídové proteiny nebo na kteroukoli léčivou nebo pomocnou látku přípravku; vrozené abnormality metabolismu aminokyselin; závažna hyperlipidémie nebo závažné poruchy metabolismu lipidů charakt s elektrolyty navíc patologicky zvýšená plazmatická koncentrace sodíku, draslíku, hořčíku, vápníku a/nebo fosforu. Zvláštní upozornění: Přlišs rychlé podání roztoků plné parenterální výživy může vést $\mathrm{k}$ závažným nebo fatálním následkům. Infuzi je nutné okamžitě zastavit, pokud se objeví jakékoli abnormální přiznaky nebo symptomy alergické reakce (např. pocení, horečka, třesavka, bolest hlavy, kožní vyrážka nebo dyspnoe). K žádné složce vaku ani rekonstituované emulzi nepřidávejte žádný jiný léčivý prípravek nebo látky bez předchozího ověření jejich kompatibility a stability výsledného prípravku (především stability lipidové emulze). Při zahájení intravenózní infuze je vyžadováno specifické klinické monitorování. V průběhu léčby sledujte rovnováhu vody a elektrolytů, osmolaritu séra, sérové triglyceridy (nesmí v průběhu infuze překročit $3 \mathrm{mmol} / \mathrm{l})$, acidobazickou rovnováhu, krevn glukózu, jaterní a ledvinové testy, koagulaci a krevní obraz včetně destiček. Pravidelně je nutné sledovat schopnost těla odstraňovat lipidy. U pacientů s jaterní insuficiencí používejte přípravek s opatrností kvưli riziku rozvoje nebo zhoršení neurologických poruch spojených s hyperamonémií. U pacientů s renální insuficiencí používejte prípravek s opatrností, zejména v případě hyperkalémie. U pacientů s poruchami koagulace, anémií, diabetem mellitus a hyperlipidémií použivejte prípravek také s opatrností. Opatrnosti je třeba prí podávání prípravku PERIOLIMEL pacientům se zvýšenou osmolaritou, nedostatečnou funkcí nadledvin, srdečním selháním nebo plicní dysfunkcí. Nepřipojujte vaky do série, aby nedošlo ke vzduchové embolii reziduálním vzduchem obsaženým v primárním vaku. V prípadě použití periferní žily u prípravku PERIOLIMEL se může vyvinout tromboflebitida. Místo zavedení katétru je nutné denně sledovat, zda se na něm nevyskytují místní známky tromboflebitidy. Interakce s jinými léčivými přípravky: Přípravky OLIMEL/PERIOLIMEL nesmí být podávány současně s krví stejným infuzním setem, nebot' hrozí riziko pseudoaglutinace. Lipidy mohou interferovat s výsledky určitých laboratorních testů (např. bilirubin, laktátdehydrogenáza, saturace kyslíkem, krevní hemoglobin), pokud je vzorek krve odebrán před odstraněním lipidů.. Dále nesmí být podávány společně s antibiotikem ceftriaxonem, z důvodu rizika vzniku precipitátů ceftriaxon-vapenatých solí. Prípravky s elektrolyty obsahují draslík. Zvláštn pozornost je třeba věnovat pacientům uživajících draslík šetříc diuretika (napr.. amilorid, spironolacton, triamterene), inhibitory angiotenzin konvertujícího enzymu (ACE), antagonisty receptoru angiotensinu II nebo imunosupresiva takrolimus nebo cyklosporin z pohledu rizika hyperkalémie. Nežádoucí účinky: možné nežádoucí účinky mohou nastat jako následek nevhodného použití (např. předávkování, přiliš vysoká rychlost infuze). Na začátku infuze může být kterýkoli z následujících abnormálních příznaků (pocení, horečka, třes, bolest hlavy, kožní vyrážka, dyspnoe) důvodem pro okamžité přerušení podávání infuze. Časté nežádoucí účinky $(\geq 1 / 100$ až $<1 / 10)$ : tachykardie, anorexie, hypertriglyceridémie, bolest břicha, průjem, nauzea, hypertenze. Podmínky uchovávání: Uchovávejte v ochranném obalu. Chraňte před mrazem. Registrační čisla: 76/389/10-C, 76/384/10-C, 76/385/10-C, 76/387/10-C, 76/388/10-C. Datum revize: 14.5.2014. Držitel rozhodnutí o registraci: BAXTER CZECH spol. s r.o., Praha, Česká republika

Úplné souhrny informací o léčivých prípravcích OLIMEL/PERIOLIMEL naleznete na www.baxter-vpois.cz

Výdej léčivých př́pravků vázán na lékařský předpis.

Př́pravky Olimel nejsou hrazeny ze zdravotního pojištění.

Kontakt: BAXTER CZECH spol. s r.o., Karla Engliše 3201/6, Praha 5 Tel. +420225774111 